Oddvar Uleberg (f. 1974) er konstituert avdelingssjef, overlege og spesialist i anestesiologi. Ingen oppgitte interessekonflikter.

Lars Petter Bjørnsen (f. 1975) er tidligere kommunelege. Han er overlege og spesialist innen akuttmedisin fra USA og leder av Norsk Selskap for Akuttmedisin (NORSEM).

Ingen oppgitte interessekonflikter.

\footnotetext{
Litteratur

1. Stoltenberg J, Hanssen BH. Rett behandling til rett tid. Arbeiderpartiet.no. 20.6.2009

http://arbeiderpartiet.no/Aktuelt/Kommentarer/ Rett-behandling-til-rett-tid. (28.11.2011).
}

2. Lokalsykehusenes akuttfunksjoner i en samlet behandlingskjede. Sluttrapport fra arbeidsgruppe 19.3.2007. Oslo: Helse- og omsorgsdepartementet, 2007.

3. SAMDATA Nøkkeltall for spesialisthelsetjenesten 1.9.2008. Trondheim: SINTEF, 2008

4. Scenario 2030 - sykdomsutviklingen for eldre fram til 2030. IK-2696. Nasjonalt Geriatriprogram, 6-99. Oslo: Statens helsetilsyn, 1999

5. Acute medical admissions - a critical appraisal of the literature. NZHTA Report 6/1998. Chistchurch, N.Z.: New Zealand Health Techonolgy Assessment (NZHTA) - the Clearing House for Health Outcomes and Health Technology Assessment, 1998.

6. Eikeland G, Garåsen H, Jacobsen G. Finnes det alternativer til øyeblikkelig hjelp-innleggelser? Tidsskr Nor Lægeforen 2005; 125: 2355-7.

7. Diagnostiske og logistiske variabler innhentet fra Akuttdatabasen (Versjon 1.5.5. Copyright (c) Helse Vest IKT) ved Akuttmottaket på St Olavs Hospital (interne data). Trondheim: St. Olavs hospital, 2011 8. Zakariassen E. Akuttmedisinske henvendelser til AMK-sentraler i Norge - epidemiologi, hvem varsles og hvem rykker ut. Scandinavian Update Magazine 2010; 3: 54- 7 .

9. Helsetilsynet. «MENS VI VENTER ...»-forsvarlig pasientbehandling i akuttmottakene? Oppsummering av landsomfattende tilsyn i 2007 med forsvarlighet og kvalitet i akuttmottak i somatisk spesialisthelsetjeneste. Rapport. Oslo: Helsetilsynet, 2008. www.helsetilsynet.no/upload/Publikasjoner/ rapporter2008/helsetilsynetrapport2_2008.pdf (28.11.2011).

10. St.meld. nr. 16 (2010-2011). Nasjonal helse- og omsorgsplan (2011-2015).

11. ... er hjelpa nærmast! Forslag til Nasjonal handlingsplan for legevakt. Rapport nr. 1. Bergen: UNIFOB HELSE, Nasjonalt kompetansesenter for legevaktmedisin, 2009.

Mottatt 23.11. 2011 og godkjent 28.11. 2011. Medisinsk redaktør Anne Kveim Lie.

\title{
Samhandlingsreforma - på feil spor
}

\author{
I samhandlingsreforma er det gode intensjonar om meir satsing på primærhelsetenesta og godt samarbeid \\ med spesialisthelsetenesta. Desse intensjonane ser ut til å drukne i pengeflytting og forhasta avtalearbeid.
}

Sjølvsagt skal vi samhandle! I ei tid der kunnskapsmengda veks ekspotensielt, er spesialisering uunngåeleg. Dette gjer oss meir avhengige av kvarandre for å belyse fleire bitar av puslespelet. Det gjer allmennlegen enda viktigare som integrator og samlar av trådar. Samhandling er ein nøkkel for å få dette til å fungere. Hovedelementa må vere god kommunikasjon, utveksling av informasjon og kunnskap og ei god oppgavefordeling der pasientane blir teke vare på i heimkommunen, der dette er rett og forsvarleg, og vist til spesialisthelsetenesta, der dette er nødvendig.

Denne oppgavefordelinga må skje på eit fagleg grunnlag, slik at pasientane er sikra forsvarleg utgreiing og behandling. Vi treng først og fremst godt fagleg utviklingsarbeid i samarbeid mellom primærlegar og sjukehuslegar. Dette er ikkje nytt, eg minner om prosedyrepermarbeidet lokallaga i Legeforeningen dreiv i 1990-åra. For å halde eit slikt arbeid levande trengst det organisering og ressursar - ein kan ikkje satse på vedvarande dugnad.

Vi treng gode kommunikasjonsverktøy, først og fremst datasystem som fungerer i kvardagen slik at vi kan utveksle informasjon ved behov.

Vi treng styrking av primærhelsetenesta, fleire legar, men også andre faggrupper, og ressursar til å yte gode omsorgs- og rehabiliteringstenester.

\section{Kva får vi?}

Vi får kommunal medfinansiering. Fleire milliardar blir sende inn i ein runddans der dei blir tatt frå budsjetta til helseføretaka og sette inn i rammene til kommunane, så reknar staten ut kor mykje innbyggarane har brukt sjukehusa og så skal kommunane betale pengane tilbake til sjukehusa. Det er ikkje, og skal ikkje vere, kommunane som avgjer kven som skal leggjast inn og sendast til behandling. Kommunane har såleis berre marginal innverknad på denne pengestraumen. Dette er pengeflytting som aukar sysselsettinga blant pengeflyttarane og tappar ressursar frå helsetenesta.

\section{«Det er ein stor og reell} fare for at dette systemet vil svekke kommunane økonomisk og gjere det vanskelegare å styrke førebygging og eigne tenestetilbod»

Kommunane treng meir ressursar dersom dei skal yte betre og meir omfattande tenester. Det er ein stor og reell fare for at dette systemet vil svekke kommunane økonomisk og gjere det vanskelegare å styrke førebygging og eigne tenestetilbod.

Vi får eit avtalesystem mellom kommunestyre og helseføretak. Avtalane omfattar sentrale områder som ansvarsfordeling, innlegging og utskriving av pasientar, beredskap, kommunal øyeblikkeleg hjelp i eigne institusjonar, kunnskapsoverføring, fors- king, faglege nettverk, IKT-løysingar med meir. Avtalane skal inngåast under tidspress utan at det er rom for refleksjon, utgreiing og forankring, noko som er nødvendig for å få til gode løysingar. Den mest sentrale samhandlingsaktøren i kommunane, fastlegane, har ingen plass i avtalesystemet. I skrivande stund, seks veker før reformen skal tre i kraft, er enno ikkje sentrale forskrifter som legg premiss for dette arbeidet på plass.

Vi får ei IT-satsing på papiret. I realiteten ikkje er ho ikkje god nok til å sikre oss dei arbeidsverktøya vi treng og det som skal til for at dei skal snakke godt samen.

Vi får ikkje den satsinga vi treng på eit godt fagleg utviklingsarbeid mellom fastlegar og sjukehusspesialistar for verkeleg å utvikle samhandling.

Vi treng ein samhandlingsreform, men denne reformen er på feil spor.

\section{Ottar Grimstad}

ottar@grimstad.me

Hareid legesenter

Hareid

Ottar Grimstad (f. 1950) er spesialist i allmennmedisin og samfunnsmedisin og kommuneoverlege og fastlege i Hareid kommune. Ingen oppgitte interessekonflikter. 